Hydrobiologia vol. 43, 1--2 pag. 93--107, 1973.

\title{
The Status of Agardhiella tenera and Agardhiella baileyi (Rhodophyta, Gigartinales)
}

by

\author{
Michael J. Wynne \& WM. Randolph Taylor
}

\begin{abstract}
Evidence is presented to support the placement of Agardhiella tenera in Solieria (as S. tenera comb. nov.) for the reason that a large fusion cell is present in the center of the cystocarp. Since A. tenera is the type species of the genus, Agardhiella Schmitz (1896) becomes a junior synonym of Solieria J. Agardh (1842). It is argued that $A$. baileyi, upon which the generic description of Agardhiella was based, is generically distinct from Solieria, and Neoagardhiella gen. nov. is proposed, with $\mathcal{N}$. baileyi as the type species. Agardhiella ramosissima is also transferred into this new genus. The old observations of Solieria as a procarpial genus made by BORNET \& ThUReT (1880) are reinforced by the present observations. This situation in the type genus of the family is contrasted with the nonprocarpial condition known in several other genera at present considered members of the Solieriaceae.
\end{abstract}

\section{INTRODUGTION}

The fact that two different taxa had been passing under the name Agardhiella tenera (J. Agardh) Schmitz was first called to our attention by TAYLOR (1966) and later in more detail by TAYLOR \& RHyne (1970). The nomenclatural type was based upon plants collected in the West Indies; the lectotype was designated (TAYLOR \& Rhyne, 1970) to be a specimen from Puerto Rico and now preserved in the Herbarium of the Universitets Botaniska Museum, Lund. However, the generic description (Osterhout, 1896; Kylin, 1928) was based upon plants collected at Woods Hole, Massachusetts, in southern New England. This latter alga was tentatively named Agardhiella baileyi (HARvey ex KützIng) TAYlor and lectotypified with a specimen originating from Long Island, New York, now preserved in the KützIng Herbarium at Leiden. It was distinguished

Department of Botany, The University of Texas at Austin, Austin, Texas 78712; Deparment of Botany, The University of Michigan, Ann Arbor, Michigan, 48104 
from the southern species (i.e., $A$. tenera sensu stricto) on habit characteristics as well as on anatomical grounds. Furthermore, A. tenera s. s. appeared from preliminary evidence to actually belong to the genus Solieria, another genus in the same family Solieriaceae. The final disposition of these two entities (namely, A. tenera and A. baileyi) awaited collections of cystocarpic material for a more critical examination of female reproductive stages. Collections of $A$. tenera from the Texas coast have provided us with the opportunity to reach certain conclusions regarding the status of these two taxa as well as their relationship to other species.

\section{HISTORIGAL BAGKGROUND}

Schmitz (1889) introduced the genus Agardhiella as a nomen nudum but later (in Schmitz \& HAUPTFLEISGH, 1896) provided a full description. The type species, $A$. tenera, was originally Gigartina tenera J. Agardh (1841) from the West Indies. Much of our understanding concerning reproductive stages was contributed by the detailed investigations of OSTERHOUT (1986) and KyLIN (1928). Both authors reported a tissue of small cells lying in the center of the cystocarp. It is important to appreciate the fact that the specimens upon which these observations were carried out originated from the northern distributional range of the plants commonly called $A$. tenera.

The genus Solieria was established by J. AGARDH (1842) and based upon Delesseria chordalis C. AgARdh (1822), a plant occurring in southern Europe. These two genera, Solieria and Agardhiella, were distinguished by KyLIN (1956) on the criterion that the cystocarp of Solieria contained in its center a large, spherical fusion cell, whereas the center in his conception of Agardhiella contained a small-celled tissue. KyLin (1928) also referred to the fact that auxiliary cells were not recognizable prior to fertilization in Solieria, but auxiliary cells were detectable before fertilization in his Agardhiella plants. KyLIN regarded both genera as nonprocarpial.

\section{Present observations}

Examination of dried cystocarpic specimens of West Indian plants of Agardhiella tenera and the observation of an apparently hollow central region caused TAYLOR \& RHYNE (1970) to see some resemblance to the genus Solieria. Therefore, they expressed serious doubt that the northern and the southern plants $(A$. baileyi and $A$. tenera, respectively) could be retained in the same genus. Further studies of 
recently collected specimens of the southern plant (i.e., genuine $A$. tenera) have reinforced their preliminary suspicions and have demonstrated the reality of a large central fusion cell, which is characteristic of Solieria.

Sections of cystocarpic material* revealed various manifestations of fusion cells comparable to the type figured for Solieria (KYLIN, 1932) and entirely at variance with the small-celled tissue which has been associated with the northern plant ( $A$. baileyi). Figures 1 and 6 present some aspects of fusion cells in $A$. tenera.

Differences regarding the carpogonial branches may be cited. Material of Agardhiella baileyi** from Cape Cod, Massachusetts, was used. Carpogonial branches (Figs. 7 and 8) typically consisted of 3 cells, although occasional 4-celled carpogonial branches were observed. The basal cell, which is connected to a large, irregularly shaped supporting cell, is usually spherical and the largest cell of the carpogonial branch; it is multinucleate and has a gelatinous zone surrounding it. The hypogynous cell, situated between the basal cell and the carpogonium, is usually broader than long and often is protuding on one side. Osterhout (1896, pl. 21, fig. 13) and KyliN (1928, fig. $43 \mathrm{E}$ ) also illustrated this distinctive hypogynous cell. The carpogonium, following fertilization, will send out an oöblastic filament (Figs. 9 and 10) or filaments directly to the auxiliary cells, which are recognizable prior to fertilization. The auxiliary cell itself (Fig. 11) has a single enlarged nucleus (stainable with haematoxylyn) and is filled with starch. It bears three large cells, which in turn give rise to branched filaments. The presence of such clusters of densely staining cells, including pre-formed auxiliary cells, agrees with the observations of Osterhout (1896) and Kylin (1928). An auxiliary cell with the attachment of an oöblastic filament is illustrated Fig. 11).

Squashed preparations of Agardhiella tenera (Wynne 3225) revealed large numbers of carpogonial branches (Figs. 2-5). Certain differences from $A$. baileyi may be pointed out. Although these carpogonial branches also were typically comprised of 3 cells and the basal cell was the largest and multinucleate, the hypogynous cell was longer than broad and was symmetrical rather than protruding on one side. We could find no clearcut evidence of auxiliary cells; this subject will be resumed in the discussion.

Other distinguishing criteria between A. tenera and A. baileyi may

\footnotetext{
* Wynne 3225, southwest jetty at Port Aransas, Nueces County, Texas; collected by Robert Elias; 12-xii-1970.

** Wynne 3310, West Falmouth Jetty, Barnstable County, Massachusetts; collected by Richard WETHERBEe; 21-vii-1971.
} 


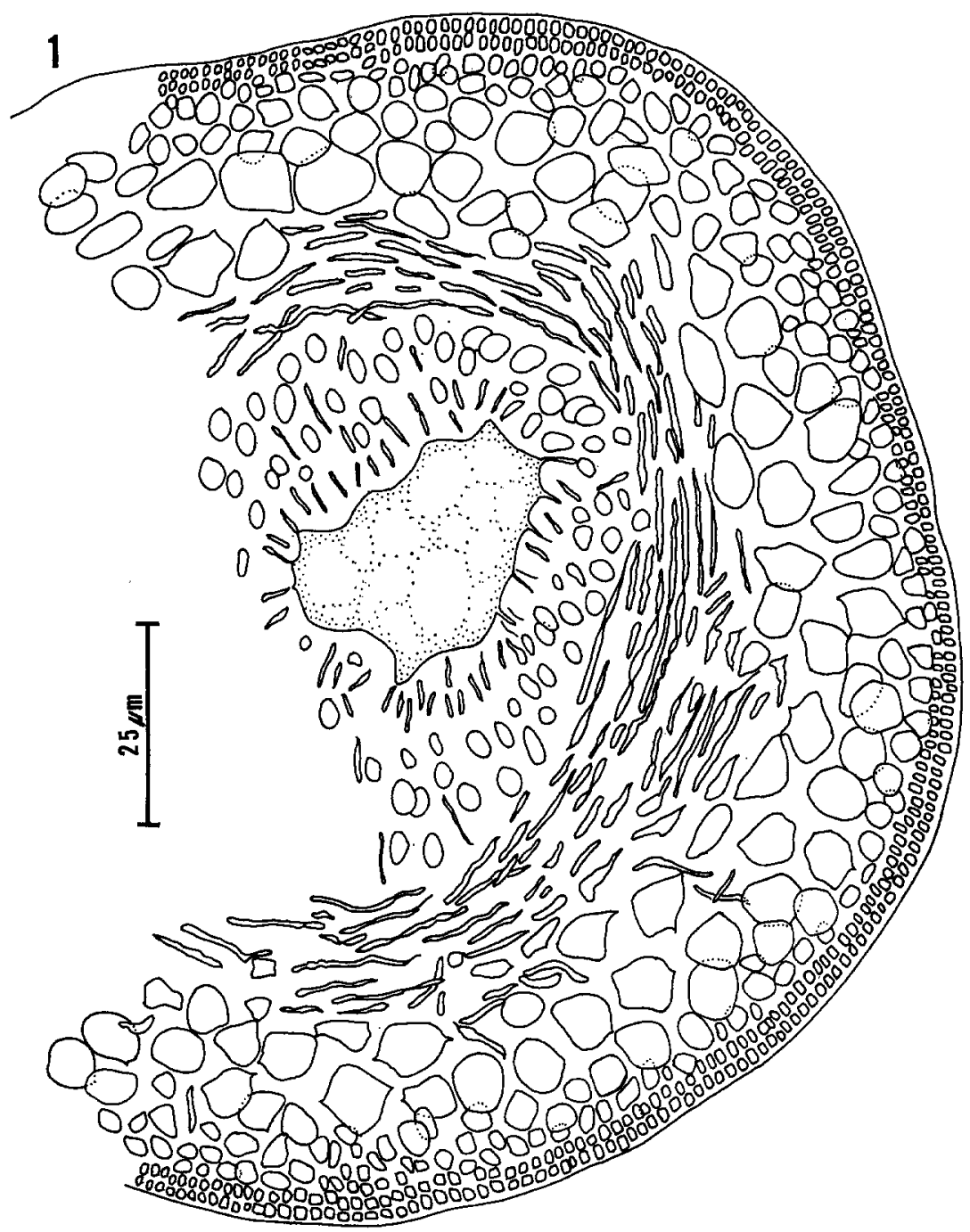

Fig. 1. Solieria tenera. Transection of mature cystocarp with fusion cell.

be enumerated. TAylor \& Rhyne (1970, p. 12) noted that the dimensions of the tetrasporangia in $A$. baileyi were twice those of $A$. tenera. Further measurements made on liquid-preserved specimens of these two species confirm this additional characteristic for distinguishing them. Tetrasporic specimens from the same collection from Massachusetts (Wynne 3310) provided the following data: zonate tetrasporangia $60-74 \mu \mathrm{m}$ in length and $28-42 \mu \mathrm{m}$ in diam. Although these figures are somewhat less than those provided by 


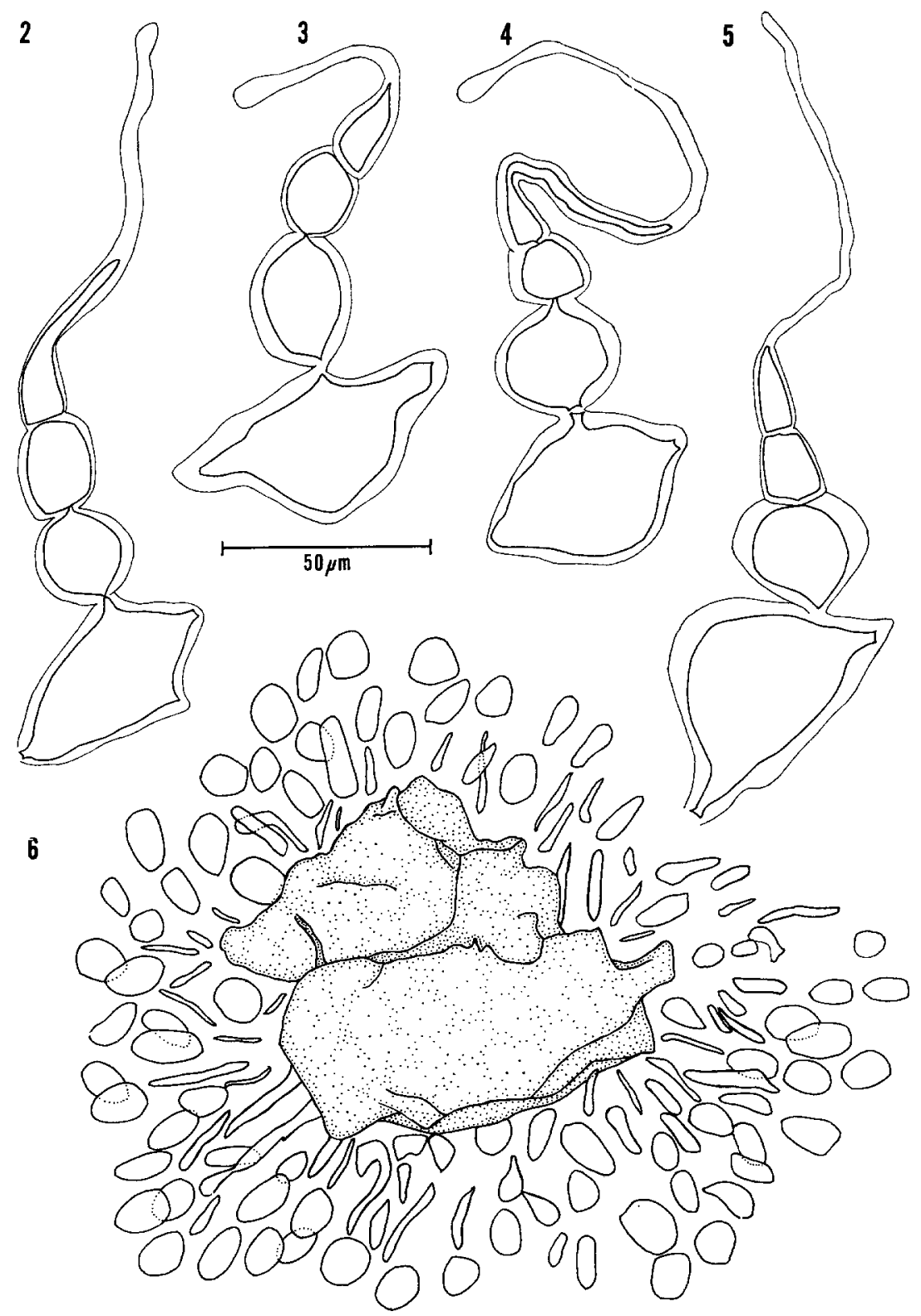

Figs. 2-6. Solieria tenera. Figs. 2-5, carpogonial branches, Fig. 6, fusion cell with carposporangia in young cystocarp.

TAYLOR \& RHYNE, they overlap their measurements and are based on liquid-preserved material rather than dried and re-soaked samples. Similarly, measurements were tabulated on liquid-preserved speci- 


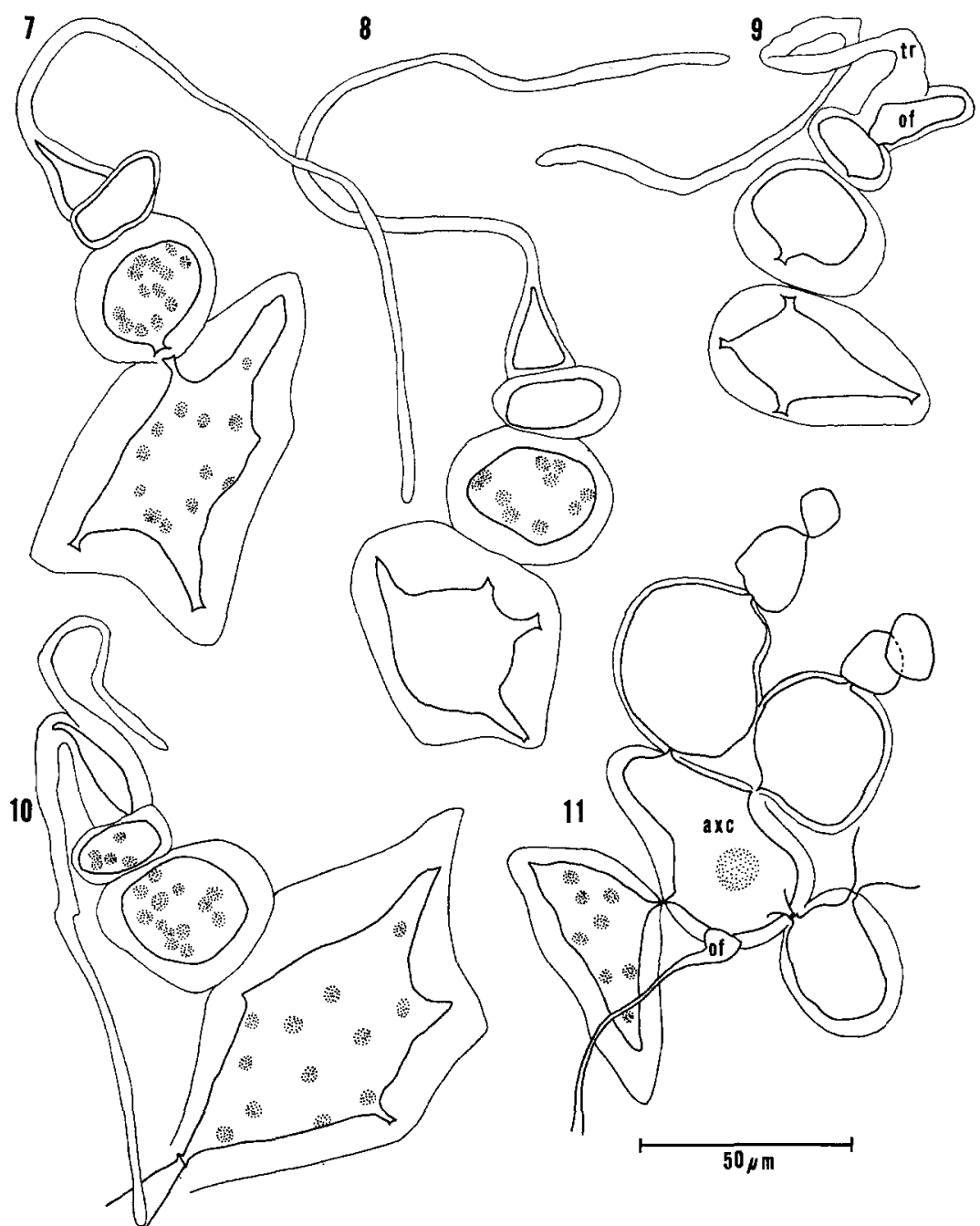

Figs. 7-11. Neoagardhiella baileyi. Figs. $7 \&$ 8, carpogonial branches. Figs. $9 \& 10$ oöblastic filaments (of) arising from fertilized carpogonium, with withered trichogyne (tr). Fig. 11, auxiliary cell ( $a x c)$ with attached oöblastic filament, auxiliary cell has a single large nucleus.

mens of $A$. tenera; tetrasporangia ranged from 27 to $33 \mu \mathrm{m}$ in length and 17 to $23 \mu \mathrm{m}$ in diameter. Again, although these values are less than those stated by TAYLOR \& RHYNE, they still tend to overlap, and, more significantly, they confirm their generalization that the tetrasporangia of the northern plant (i.e., A. baileyi) are double the size of the southern plant (i.e., genuine $A$. tenera).

The anatomical difference of conspicuous, thick-walled and con- 
tinuous medullary filaments present in $A$. tenera contrasted with the absence of such medullary filaments also serves to differentiate these two superficially similar taxa. Of course, the major portion of the medullary tissue in both is comprised of slender, thin-walled filaments coursing in all directions. Finally, the loose, fibrous basal portion of $A$. tenera is in marked contrast to the simple basal attachment of $A$. baileyi. Unfortunately, the basal portion is often lost in the process of collecting and preserving specimens of $A$. tenera; but it serves as a usefull diagnostic trait, as TAYLOR \& RHYNE (1970) have pointed out.

\section{Emendation of AGardhiElla tenera}

The structure of the cystocarp in Agardhiella tenera, as has been discussed above, makes it necessary that this species be included in the genus Solieria. The question might be asked whether the species of the West Indies is separable from the type species, $S$. chordalis. It is to be remembered that at one point HARvey (1853) listed $S$. chordalis as occurring along the east coast of North America from Cape Cod to Key West, Florida. In addition, a plant has been distributed in the Phycotheca Boreali-Americana (Collins, Holden \& SeTCHELL, 1897) as $S$. chordalis, originating from Jupiter Inlet, Palm Beach County, Florida. Finally, it may be noted that Colcins (1901) recorded both Agardhiella tenera and Solieria chordalis from Jamaica.

European material* of authentic Solieria chordalis was examined. Certain differences exist between Solieria chordalis of southern Europe and the plant under consideration from the western Atlantic. In the original description of S. chordalis C. AgARdH (1822) referred to the dichotomous branching of this plant. Branching. is not so regularly dichotomous in so-called $A$. tenera. Plants of $S$. chordalis have a much larger number of short ultimate branches, giving a proliferous appearance. Axes of $S$. chordalis seem to be less robust than $A$. tenera, seldom more than $1 \mathrm{~mm}$ in diam. and with a very dense medulla of compactly arranged filaments. Plants of both species agree in having fibrous holdsfasts (cf. Bornet \& Thuret, 1880 , p. 188; DeTonı, 1897, p. 366) and in lacking the spindle-

* FRANCE: Ille-et-Vilaine, Saint-Malo, E. Chemin, 11 Sept. 1928 (WRT); A. Hamel-Joukov (Algues de France No. 189), Sept. 1931 (UM). Côtes du Nord, Cap Fréhel, W. R. TAYlor 26644, Sept. 1959 (WRT). Finistère, Brest, St. Marc \& Banc du Moulin-Blanc, J. Feldmann 8969, 4 April 1954 (UM); Banc au Ros-Bren, A. Dizerbo, 1963 (UM). Morbihan, Golfe du Morbihan, herb. G. Thuret, 17 August 1872 (UM). Vendée, Ile de Noirmoutier, J. Cabioch, Sept. 1967 (TEX). 
shaped branches tapering to the point of their attachment, which is so characteristic of the $A$. baileyi. Our conclusion is that the American plant seems to be specifically different from the European $S$. chordalis, and thus the following transfer is proposed:

Solieria tenera (J. AGARDH) comb. nov.

Basionym: Gigartina tenera J. Agardh, 1841, p. 18.

Synonyms: Sphaerococcus tener (J. AgaRdH) KützIng, 1849, p. 777. Rhabdonia tenera (J. AgardH) J. AgardH, 1851, p. 354. Agardhiella tenera (J. Agardh) Schmitz in Schmitz \& HauptFleisGh, 1896, p. 371.

\section{REASSIGNMENT OF AGARDHIELLA BAILEYI}

Since the nomenclatural type of Agardhiella tenera is congeneric with Solieria J. Agardh (1842), Agardhiella Sahmitz must be regarded as a junior synonym of Solieria. Since the species upon which the description of Agardhiella is based (presently, A. baileyi) has been demonstrated to be generically distinct from Solieria, this species must be transferred to some other generic name. There is no available generic name nor an appropriate described genus. Thus, a new genus mist be established. The name Neoagardhiella is hereby designated as that of the new genus.

Neoagardhiella gen. nov.

Plantae erectae, ramosae, unus vel aliquot sulculi ex haptero discoideo enascentes; rami cylindrici, radiatim aut distiche ordinati; cortex compactus, e cellulis externis parvis, atque interioribus maioribus compositus; cellulae interiores rhizoidea filamentosa quae filamentis centralibus multis systematis multiaxialis crescentiae ad medullam formandam intermiscunt efficientes : plantae unisexuales; spermatangia primum in maculis parvis in ramis iuvenibus, postea in areolis amplis formata; rami carpogoniales in cellulis corticalibus interioribus lateraliter nati, typice tricellulares (interdum quadricellulares), trichogyna superficiei thalli abrupte observa; cellula auxialiares ut cellulae intercalares filamentorum corticalium amplificatae compactioresque agnoscibiles; communicatio cellulae auxiliari filamento coniungente e carpogonio fecundato enascente efficitur; cystocarpi sparsi inclusique, cortice superiacente, autem, saepe conspicue eminente; cystocarpus e tela centrali sterili atque cellulis periferalibus terminalibus quae in carposporangia evolvunt compositus; carposporangia per ostiolum liberata; filamenta cystocarpum dense circumscribentia tegentiaque, et filamenta quae e tela centrali sterili radiatim extendunt contingentia; tetrasporangia in indi- 
viduis isomorphicis quae super thallum distribuntur producta, in cortice exteriore inclusa, zonate divisa.

Neoagardhiella gen. nov.

Plants erect, branching, with one to several shoots from a discoid holdfast; branches cylindrical, radially or distichously arranged; cortex compact, composed of outer smaller cells and inner larger cells, the latter giving rise to filamentous rhizoids which intermix with many central filaments of the multiaxial growth system to form the medulla; plants unisexual; spermatangia formed in small patches on young branches, later in extensive areas; carpogonial branches borne laterally on inner cortical cells, typically 3-celled (occasionally 4-celled) with trichogyne turning abruptly toward the thallus surface; auxiliary cells recognizable as enlarged denser intercalary cells of cortical filaments; communication with an auxiliary cell is made by a oöblastic filament from a fertilized carpogonium; cystocarps scattered and embedded, but the overlying cortex often conspicuously protruding; cystocarp composed of a central sterile tissue with peripheral, terminal cells developing into carposporangia, which are released through an ostiole; a thick investment of filaments surrounding the cystocarp and in contact with filaments radiating from the central sterile tissue; tetrasporangia produced on isomorphic individuals, distributed over the thallus, embedded in the outer cortex, zonately divided.

Type species: Neoagardhiella baileyi (HARvey ex KützING) comb. nov. Basionym: Rhabdonia baileyi Harvey ex Kützing, 1866, p. 26, pl. 74 .

Synonym: Agardhiella baileyi (Harvey Ex KützIng) TAylor in TAYlor \& RHYNe, 1970, p. 13.

Agardhiella tenera sensu Osterhout, 1896, sensu KYLIN, 1928.

\section{DisTRIBUTIONAL NOTES}

As presently circumscribed, Solieria tenera in the western Atlantic is basically a warm water species confined to the Caribbean Sea and the Gulf of Mexico, whereas Neoagardhiella baileyi is primarily a cold water species ranging northward to southern New England (TAYLOR, 1962; TAYLOR \& RYHNE, 1970). However, this statement does not preclude their distributional overlap. Indeed, both species can be found in the same vicinity, e.g., at Port Aransas, Texas*. Yet

* We are grateful to Dr. Peter Edwards for providing us with his collection data for these two species. 
interestingly there exist significant seasonal and niche differences as to their occurrences. Solieria tenera grows on the exposed jetty at Port Aransas in the upper sublittoral zone and can be collected throughout the year, with its peak of development during summer and autumn. It seems to prefer a wave-swept habitat. Neoagardhiella baileyi, on the other hand, is here restricted to quiet, protected Redfish Bay, where it grows attached to shells. There it has been observed only in the spring, namely, February to April. Such ecological differences along with the already stated anatomical and reproductive differences, support the idea that two very distinct entities are involved.

The distribution of Solieria tenera ranges to West Africa. Due to the kindness of DR. D. M. JoHn of the University of Ghana, we have been able to examine several specimens collected from near Tema and Accra in Ghana. Tetrasporangia measure $28-34 \mu \mathrm{m}$ in length and $16-20 \mu \mathrm{m}$ in diameter (based upon re-wet pressed samples), and thick-walled, continuous medullary filaments were apparent. Although we were unable to check cystocarpic plants, these above traits sufficiently relate the plant to $S$. tenera.

Joly (1965) listed 'Agardhiella tenera' from the State of São Paulo, Brazil. His illustration of a transection of a cystocarp (pl. XXVI, fig. 366) revealed what appears to be a large fusion cell in the center of the cystocarp. The plant in question would appear to be Solieria tenera.

One unresolved issue concerns Børgesen's (1919) description of auxiliary cells and oöblastic filaments in his collection from the Virgin Islands. We have examined his specimens from St. Croix, St. Thomas, and St. Jan of the Virgin Islands, now preserved in the Botanical Museum of the University of Copenhagen, and find them to be exclusively $S$. tenera. It is uncertain what material BøRGESEN based his figures 356 and 357 upon; only one cystocarpic plant (from St. Croix) was present among his Caribbean specimens.

In reference to other species of Solieria, we have examined a cystocarpic specimen* of S. robusta (GREV.) KYLIN and observed the large fusion cell in the cystocarp typical of the genus. This Australian species, however, is a much coarser, broader plant than either $S$. chordalis or $S$. tenera. Likewise, $S$. dura (Zanardini) Schmitz from the Red Sea is a much heavier, irregularly branched plant (ZANARDINI, 1858, pl. 11, fig. 1).

* Norris 1957 (TEX), Narrawong Beach, Portland, Victoria, Australia; 14-iv1959. 


\section{DisPosition OF OTHER SPECIES OF AGARDHIELLA}

Additional species of Agardhiella have been recognized, such as $A$. ramosissima, A. coulteri, and $A$. mexicana. Agardhiella ramosissima (HARvey) Kylin has been recorded from Florida and various islands in the Caribbean to Venezuela and Brazil (TAYLOR, 1960; JoLy et al., 1968). It is easily distinguished by its branches of lower rank being flattened and by the distichous arrangement of all the branchlets.

We have examined collections* of cystocarpic Agardhiella ramosissima and have observed the cystocarps to possess a central tissue of small cells comparable to that of Neoagardhiella baileyi rather than a large fusion cell. Joly et al. (1968), who recorded A. ramosissima var. dilatata from the State of Ceará, Brazil, depicted (pl. 2, fig. 3) a sectioned cystocarp with a central region composed of a tissue of small cells. We are thus induced to transfer $A$. ramosissima to $\mathcal{N e o -}$ agardhiella.

Neoagardhiella ramosissima (HARvey) comb. nov.

Basionym: Chrysymenia ramosissima Harvey, 1853, p. 190, Pl. 30, fig. $\mathrm{B}$.

Synonym: Rhabdonia ramosissima (HARvey) J. Agardh, 1876, p. 593. Agardhiella ramosissima (HARVEY) KYLIN, 1932, p. 17.

Two varieties of this species have been recognized (AGARDH, 1885; TAYLOR, 1960), and they are accordingly included here.

$\mathcal{N}$ eoagardhiella ramosissima v. Harveyana (J. AgARDH) var. nov.

Basionym: Rhabdonia ramosissima a. Harveyana J. Agardh, 1885, p. 85.

Neoagardhiella ramosissima v. dilatata (J. AgARDH) var. nov.

Basionym: Rhabdonia ramosissima b. dilatata J. AgARDH, 1885, p. 85.

A related species of the Gulf of Mexico, Eucheuma acanthocla-

* Cystocarpic specimens examined: FLORIDA: Dade County, between Mangrove Key and Key West, W. R. TAYLOR 10304, 31 May 1925 (WRT); Jupiter Inlet. Mrs. G. A. HALL, (var. dilatata), 10 Sept. 1896 (PB-A in UM, WRT, and TEX). Citrus County, Buoy 2 off Homosassa River, D. Cheney 70-118, 20 Sept. 1971 (USF). Non-cystocarpic specimens examined: FLORIDA: Dade County, Key West, Mrs. G. A. HALl, April 1897 (PB-A in UM and TEX); Levy County, Cedar Key, E. L. Pierce 2, 11 August 1949 (UM) and E. L. Pierce 14, 23 August 1949 (UM). Sarasota County, $50 \mathrm{ft}$. depth off Sarasota, C. Dawes 7040, 30 June 1971 (USF). Lee County, C. Dawes 2062, 25 June 1964 (USF). Monroe County, Content Key, Dawes 3917, 24 June 1966 (USF). NETHERLANDS WEST INDIES: Aruba I., cove at Punta Basora, W. R. TAYLOR 20249 (var. dilatata), 10 April 1939 (WRT). 
dum* (Harvey) J. Agardh, presents a superficially similar appearance to Neoagardhiella ramosissima. Both species tend to have a flattened primary axis with a distichous arrangement of branches in $5-6$ ranks and a fleshy texture. But the cervicorn, often secund final branches of $E$. acanthocladum and the denser arrangement of medullary filaments should serve to separate this species from $\mathcal{N}$. ramosissima. TAYLOR (1928, pl. 31, fig. 1) depicted a specimen of $E$. acanthocladum.

In his description of the female plants of Pacific Coast Agardhiella coulteri (HaRvey) Setchell, Smith (1955) claimed that the auxiliary cell is distinguishable prior to fertilization from other vegetative cells by its denser protoplasm. He also depicted the cystocarp as being composed of a mass of small-called intertwined filaments which radiate outwards. No evidence of a large fusion cell was shown. Dr. I. A. Аввотт (pers. comm.) has confirmed this structure of the cystocarp. Both of these traits indicate that the Pacific Coast species belongs to Neoagardhiella rather than Solieria. Whether it can be legitimately separated from the Atlantic $\mathcal{N}$. baileyi is debatable. We tend to agree with those workers (Howe, 1914; TAYLOR, 1945; DAwson, 1961) who have regarded it as conspecific with the Atlantic species and therefore to be called $\mathcal{N}$. baileyi.

Agardhiella mexicana DAwsON (1944) has been regarded (TAYLOR, 1945; Dawson, 1961) as a synonym of ' $A$. tenera' (i.e., $\mathcal{N}$. baileyi).

\section{Discussion}

The Solieriaceae has been characterized as a nonprocarpial family (Kylin, 1932, 1956; FrITSCH, 1959) primarily on the basis of investigations on Neoagardhiella baileyi (formerly Agardhiella tenera p. p.) (Osterhout, 1896; Børgesen, 1919; Kylin, 1928). It is worth while to briefly trace the development of our concept of some related families of the Gigartinales. KyLIN (1925) divided the large family Rhodophyllidaceae into two groups: the procarpial family Rhodophyllidaceae in the restricted sense, containing Rhodophyllis, Cystoclonium and Euthora, and the nonprocarpial Rhabdoniaceae, a new family containing Rhabdonia, Agardhiella, Anatheca, Flahautia, and Solieria. This latter family was subsequently subdivided by KyLIN (1932) on the basis of vegetative construction: Rhabdoniaceae was characterized by uniaxial growth (with the genera

* Specimens examined: FLORIDA: Sarasota County, $55 \mathrm{ft}$. depth off Sarasota, C. Dawes 7058, 18 July 1971 (USF). Monroe County, Content Key, C. Croley 985, 18 Feb. 1967 (USF). Off Florida Keys $\left(81^{\circ} 35^{\prime} / 24^{\circ} 47^{\prime}\right)$, C. Dawes 2632, April 1965 (USF). 
Rhabdonia, Catenella, Erythroclonium, and Areschougia) and the Solieriaceae (a name first used by HAUCK, 1885) was characterized by multiaxial growth (with the genera Thysanocladia*, Flahautia, Sarcodiotheca, Agardhiella, Solieria, Sarconema, Eucheuma, Anatheca, Meristotheca, and Euryomma). Several genera have subsequently been added to the Rhabdoniaceae (cf. Kylin, 1956; Searles, 1968); however the Solieriaceae has remained relatively unchanged.

The investigations of Bornet \& THuRet (1880) revealed the apparent origin of the gonimoblast directly from the carpogonial branch (= their 'procarp'). This observation seems to have been ignored by later workers. KYLIN (1932) clouded the issue by suggesting that auxiliary cells were merely recognizable before fertilization and that the family Solieriaceae lacked procarps. In our own studies, the apparent absence of separate auxiliary cells and of oöblastic filaments strongly suggests that a cell of the carpogonial branch acts as the auxiliary cells, although we have not observed the critical stages. However, we see no reason to doubt the original observations made on Solieria chordalis by Bornet \& ThuRET (1880).

Such a new interpretation of the Solieriaceae as procarpial, based on the type genus, would necessitate the separation of Solieria from the other genera in the family which are known to be nonprocarpial (e.g., Neoagardhiella, Sarcodiotheca, Turnerella, Opuntiella and Callophycus**). Solieria agrees with the monotypic family Rissoellaceae in having a large fusion cell at the center of the cystocarp, the occurrence of procarps, zonately divided tetrasporangia, an inward development of the gonimoblast, and a multiaxial system of growth; but some significant reproductive differences exist between these two genera (cf. Kylin, 1956; SahotTer \& Cabioch, 1963).

Several genera presently included in the Solieriaceae have not been subjected to critical studies regarding their immediate postfertilization development. It is apparent at present that an important difference separates the procarpial genus Solieria, the name to which the family is tied, from several other genera contained in the family, which are known to be nonprocarpial. This criterion has served as a fundamental means of delineating families of this order. So, in conclusion, we wish to call attention to this problem of an apparently heterogeneous assemblage currently constituting the Solieriaceae, but we feel that a review of the reproductive features of these other genera from material, not from the literature, should be carried out in the light of what we have found in Solieria before family reorganization is attempted.

* This genus is now known as Callophycus (Silva, 1957).

** See Hewitt, 1960. 


\section{Acknowledgements}

We are grateful to the following persons for the loan of specimens: Jacqueline Cabioch of Roscoff, David M. John of Legon, Jørgen Benth Hansen of Copenhagen, and Clinton J. Dawes of Tampa. We also wish to thank Dr. Hannah Croasdale for providing us with the Latin description. This study was supported in part by Grant GB-3186 from the National Science Foundation to the second author, which help is gratefully acknowledged.

\section{REFERENCES}

Agardh, C. A. - 1822 - Species Algarum. Vol. 1 (2). Lund, p. 169-531.

Agardh, J. G. - 1841 - In Historiam Algarum Symbolae. Linnaea 15: 1-50, $443-457$.

Agardh, J. G. - 1842 - Algae maris Mediterranei et Adriatici. $x+164$ p. Paris.

Agardh, J. G. - 1851 - Species genera et ordines Floridearum. Vol. II. Algas Florideas complectens. xii $+1291 \mathrm{p}$. Lund.

Agardh, J. G. - 1876 - Species genera et ordines Algarum. III. Epicrisis systematis Floridearum. vii +734 p. Lund.

Agardh, J. G. - 1885 - Till algernas systematik. VII. Florideae. Acta Universitatis Lundensis $21.117+$ [3] p., $1 \mathrm{pl}$.

Børgesen, F. - 1915-1920 - The marine algae of the Danish West Indies. Vol. II. Rhodophyceae, with addenda to the Chlorophyceae, Phaeophyceae, and Rhodophyceae. Dansk Bot. Arkiv 3 (1). 498 p.

Bornet, E. \& Thuret, G. - 1880 - Notes algologiques no. 2. Paris.

Collins, F. S. - 1901 - The algae of Jamaica. Proc. Amer. Acad. Arts \& Sci. 37 : $231-270$.

Collins, F. S., Holden, I. \& Setchell, W. A. - 1897 - Phycotheca BorealiAmericana. (Exsiccata). Fascicle 8. Malden, Mass.

Dawson, E. Y. - 1944 - The marine algae of the Gulf of California. Allan Hancock Pacific Exped. 3: 189-453, 3 tables, pls. 31-77.

Dawson, E. Y. - 1961 - Marine red algae of Pacific Mexico. Part 4. Gigartinales. Pacific Nat. 2: 189-343, 63 pls.

DeToni, G. B. - 1897 - Sylloge Algarum, 4 (1): Sylloge Floridearum, i- $x+$ i-lxi $+1-388$. Padua.

Fritsch, F. E. - 1945 - The structure and reproduction of the algae. Vol. 2. Cambridge. xiv +939 pp., 336 figs., frontis., 2 maps.

Harvey, W. H. - 1853 - Nereis Boreali-Americana. II, Rhodospermae. Smithsonian Contrib. to Knowledge 5 (5): 1-258, pls. 13-36. Washington, D. C.

Hauck, F. - 1883-1885 - Die Meeresalgen Deutschlands and Oesterreichs. In L. Rabenhorst, Kryptogamen-Flora von Deutschland, Oesterreich und der Schweiz. Vol. 2. Leipzig. xxiv +575 pp., 236 figs., 5 pls.

HewrtT, F. E. - 1960 - A morphological study of three South African Gigartinales. Univ. Calif. Publ. Bot., 32: 195-234, 35 figs., pls. 26-32.

Howe, M. A. - 1914 - The marine algae of Peru. Mem. Torrey Bot. Club 15: 1 -185, 44 text-Figs., 66 pls.

Joly, A. B. - 1965 - Flora marinha do litoral norte do Estado de Sao Paula e regioes circunvizinhas. Boletim No. 294, Fac. Fil. Cienc. e Letras da Univ. Sao Paulo, Botanica 21, 393 p., 3 maps, 59 pls. 
Joly, A. B., Ferreira, M. M., Pinheiro-Vieiera, F. \& Yoneshigue-Braga, Y. 1968 - Additions to the American South Atlantic marine algae. I. Arq. Est. Biol. Mar. Univ. Fed. Ceará 8 (2): 177-181, 3 pls.

Kützing, F. T. - 1849 - Species Algarum. vi + 922 p. Leipzig.

Kützing, F. T. - 1866 - Tabulae Phycologicae, 16: i + 35 p., 100 pls. Nordhausen.

Kyl.n, H. - 1925 - The marine red algae in the vicinity of the Biological Station at Friday Harbor, Wash. Acta Universitatis Lundensis, series 2, 21 (9): $1-87,47$ figs.

Kylin, H. - 1928 - Entwicklungsgeschichtliche Florideenstudien. Acta Universitatis Lundensis, series 2, 24 (4): 1-127, 64 figs.

Kylin, H. - 1932 - Die Florideenordnung Gigartinales. Acta Universitatis Lundensis, series 2, $28(8): 1-88,22$ figs., 28 pls.

Kylin, H. - 1956 - Dic Gattungen der Florideen. xv + 673 p., 458 figs. CWK Gleerups. Lund.

Osterhout, W. J. V. - 1896 - On the life-history of Rhabdonia tenera J. Ag. Ann. Bot. 10: 403-427, pls. 20 \& 21.

Schmiтz, F. - 1889 - Systematische Übersicht des bisher bekannten Gattungen der Florideen. Flora 72: 435-456, pl. 21.

Schmitz, F. \& Hauptfleisch, P. - 1896 - Rhodophyllidaceae. In Engler \& Prantu, Natürlichen Pflanzenfamilien I (2), p. 366-382, figs. 222-227.

Schotter, G. \& Cabioch, J. - 1963 - Sur les organes mâles de Rissoella verruculosa (Bertol.) J. Ac. (Floridées). C. R. Acad. Sci. [Paris] 256: 13361339.

Searles, R. B. - 1968 - Morphological studies of red algae of the order Gigartinales. Univ. Calif. Publ. Bot. 43. vi $+[1]+100$ pp.

Silva, P. C. - 1957 - Remarks on algal nomenclature. Taxon 6: 141-145.

Smrth, G. M. - 1955 - Cryptogamic Botany. Volume I. Algae and Fungi, ix + 546 p., 311 figs., 1 table. 2nd Ed. McGraw-Hill Book Co., Inc., New York.

TAYLOR, W. R. - 1928 - The marine algae of Florida, with special reference to the Dry Tortugas. Carnegie Inst. Wash., Publ. 379; Papers from the Tortugas Lab., 25: v + 219 p., 3 text-figs., 7 tables, 37 pls.

TAYlor, W. R. - 1945 - Pacific marine algae of the Allan Hancock Expeditions to the Galapagos Islands. Allan Hancock Pacific Exped. 12. iv + 528 p., 100 pls.

TAYLOR, W. R. - 1960 - Marine Algae of the Eastern Tropical and Subtropical Coasts of the Americas. Univ. Michigan Stud., Sci. Ser. 21. ix +870 p., 14 photos, 80 pls.

TAYlor, W. R. - 1962 - Marine Algae of the Northeastern Coast of North America. Edition 2, 2nd printing, with corrections. Univ. Michigan Stud., Sci. Ser. 13, ix +509 p., 60 pls.

TAYLOR, W. R. - 1969 - Notes on the distribution of West Indian marine algae particularly in the Lesser Antilles. Contrib. University of Michigan Herbarium 9: 125-203, 26 text-figs., 8 pls.

Taylor, W. R. \& Rhyne, C. F. - 1970 - Marine algae of Dominica. Smithsonian Contrib. Botany 3: 1-16, 2 figs.

ZANARDini, G. - 1858 - Plantarum in mari rubro hucusque collectarum enumeratio. Mem. Ist. Veneto Sci. Lett. Arti, 7: 209-309, pls. 3-14. 